\title{
The influence of intercropping broad bean with phacelia on the occurrence of weevils (Sitona spp.) and broad bean beetles (Bruchus rufimanus Boh.)
}

\author{
Andrzej Wnuk, Elżbieta Wojciechowicz-Żytko
}

Department of Plant Protection Agricultural University in Krakow

29-Listopada 54, 31-425 Kraków, Poland e-mail: awnuk@ogr.ur.krakow.pl

\begin{abstract}
A study of the influence of intercropping broad bean with phacelia on the occurrence of weevils and broad bean beetles was conducted in the years 2006-2009. The harmfulness of Sitona spp. beetles feeding on the leaves (the number of U-shape notches and the number of damaged leaves) and the harmfulness of the larvae, as well as the feeding on the broad bean root nodules was taken into account. The harmfulness of the broad bean beetle was determined by assessing the condition of the seeds. The influence of phacelia on the presence of weevils (Sitona) and broad bean beetles (Bruchus rufimanus) as broad bean pests was not observed. A smaller amount of broad bean seeds damaged by the broad bean beetle was determined only in some of the years of the study in the plots in which the phacelia was intercropped with broad bean.
\end{abstract}

Key words: broad bean pests, mixed cropping, Phacelia tanacetifolia, Vicia faba

\section{INTRODUCTION}

In modern agriculture, more and more often ecological production methods, involving the preservation of the biological diversity of agrocenoses, are taken into consideration. Activities leading to an increase of biodiversity include the application of appropriate farming techniques, and among those the use of mixed cropping (Van Emden and Dąbrowski 1994).

A reduction in the number of harmful insects in multi-species crops can stem from the fact that the presence of varied plants deters the pests or makes finding a host plant more difficult (Finch 1996, Finch and Kienegger 1999). In many cases, such planting can limit the number of pests and raise the resistance of the natural environment (Boczek 1984, Wiech 1993).

Species used in inter-row plant cropping include phacelia. High sugar and pollen content means that phacelia is one of the species that attract insects to their flowers (Jabłoński 2000). Intercropping broad bean with phacelia reduces the number of aphids Aphis fabae Scop. and increases the number of predacious syrphid larvae in its colonies, as compared to the homogenous crop (Wnuk and Wojciechowicz-Żytko 2007).

The purpose of this study was the determination of the influence of tansy phacelia (Phacelia tanacetifolia Benth.) on the occurrence of the following common broad bean pests: weevils - Sitona spp. (damaging leaves and root nodules), and the broad bean beetle - Bruchus rufimanus Boh. (feeding on seeds).

\section{MATERIAL AND METHODS}

The observations were conducted between 20062009 at the Experimental Station of the Department 
of Plant Protection located in Mydlniki, in the vicinity of Krakow. The following plant combinations were considered: 1 - broad bean sown as a homogenous crop (the control plot); 2 - broad bean with phacelia sown in the centre of the plot; 3 - broad bean with phacelia sown at the edges of the plot; 4 - phacelia intercropped with broad bean. In combinations 2 and 3, phacelia was sown in 50 $\mathrm{cm}$ wide strips.

Broad bean (Vicia faba L.) of the 'Hangdown Biały' cultivar was sown in spacing of $30 \times 50 \mathrm{~cm}$, on plots that measured $25 \mathrm{~m}^{2}$ each. The experiment was based on a method of blocks selected at random in four replications. Broad bean and phacelia were sown at the same time, at the end of March in 2007 and in the first days of April in the remaining years.

Sitona spp.: the damage caused by beetles feeding on leaves (the number of U-shape notches on the leaves and the number of damaged leaves) and larvae feeding on broad bean root nodules were considered. In each plot, 10 plants were selected and marked at random, and the number of notches was counted. Every year the analyses were conducted three times, every seven days beginning about three weeks after the plants were sown, and an average was calculated from the obtained set of measurements. During the broad bean blooming season, 10 plants from each plot were analysed once for signs of the presence of weevil larvae feeding on root nodules. The plants were gently removed together with a lump of soil and examined, looking for the larvae and counting the healthy and the damaged nodules.

Broad bean beetle: from the time the first broad bean flowers appeared, the beetles were shaken off of the plants over a sweep net. The beetles removed from the net were counted and released in the plots from which they were collected. This was repeated three times every seven days, and the average number of beetles per plant was calculated. The assessment of the damage was made on the harvested seeds (200 seeds from each of the plots), counting all beetle exit holes, after the larvae development process inside the seeds was completed. The seeds were kept in the laboratory for around two months after the harvest, at room temperature, in order to obtain a full pattern of the broad bean beetles' feeding on the seeds. In 2008, it was impossible to conduct the analysis of the pods due to hail and the resulting damage to the plants. In addition, when assessing the harmfulness, the examined seeds were divided into three groups - depending on the seed size: up to $19 \mathrm{~mm}, 20-23 \mathrm{~mm}$ and over $24 \mathrm{~mm}$. The Duncan multiple test $(\mathrm{p}=0.05)$ was used for the statistical analysis of the results.

\section{RESULTS AND DISCUSSION}

The effect of weevil beetle feeding on broad bean leaves is presented in Table 1. The number of U-shaped notches was reasonably low in all of years of the experiment; slightly more were noted in 2008. The differences between the particular years and between the combinations were relatively low. The influence of tansy phacelia on beetle broad bean feeding could not be determined - the highest numbers of notches were found on plots with phacelia intercropped with broad bean in the years 2006 and 2008; in 2007 the highest number of notches was noted in the homogenous broad been crops, whereas in 2009 it was in the plots in which phacelia was sown on the edges of the plots.

A similar situation occurred during the analysis of the root nodules, conducted in order to determine the presence of weevil larvae (Tab. 2). During the years of the experiment the average number of larvae per plant was similar (both the healthy and the damaged plants were considered). Significant differences were found in 2006 - the lowest number of larvae was noted in the plot with the homogenous crop - and in 2007, when the largest number of larvae was detected in the plot where broad bean was intercropped with phacelia. In 2007, the largest number of plants damaged by weevil larvae was noted on the same plots, as compared to the other combinations. The lowest number of damaged

Table 1. Leaf damage caused by weevil beetles (Sitona spp.), depending on the method of cropping

\begin{tabular}{lcccc}
\hline \multirow{2}{*}{ Crop } & \multicolumn{3}{c}{ Average number of notches per plant } \\
\cline { 2 - 5 } & 2006 & 2007 & 2008 & 2009 \\
\hline Broad bean sown as homogenous crop & $13.6 \mathrm{ab} *$ & $12.3 \mathrm{~b}$ & $15.4 \mathrm{ab}$ & $10.6 \mathrm{a}$ \\
\hline Broad bean with phacelia sown in the centre of plot & $11.7 \mathrm{ab}$ & $8.5 \mathrm{a}$ & $14.3 \mathrm{a}$ & $11.5 \mathrm{ab}$ \\
\hline Broad bean with phacelia sown at the edges of plot & $11.1 \mathrm{a}$ & $10.0 \mathrm{ab}$ & $15.7 \mathrm{ab}$ & $12.6 \mathrm{~b}$ \\
\hline Phacelia intercropped with broad bead & $14.0 \mathrm{~b}$ & $10.9 \mathrm{ab}$ & $16.8 \mathrm{~b}$ & $11.5 \mathrm{ab}$ \\
\hline
\end{tabular}

*Means followed by the same letters in columns are not significantly different according to the Duncan test for $p=0.05$ 
Table 2. Feeding of Sitona spp. larvae on broad bean root nodules

\begin{tabular}{lcccccccc}
\hline \multirow{2}{*}{ Crop } & \multicolumn{3}{c}{ Average number of larvae per plant } & \multicolumn{3}{c}{ Percentage of damaged plants } \\
\cline { 2 - 8 } & 2006 & 2007 & 2008 & 2009 & 2006 & 2007 & 2008 & 2009 \\
\hline $\begin{array}{l}\text { Broad bean sown as } \\
\text { homogenous crop }\end{array}$ & $0.9 \mathrm{a}^{*}$ & $0.9 \mathrm{a}$ & $0.4 \mathrm{a}$ & $0.8 \mathrm{a}$ & $50.0 \mathrm{ab}$ & $55.0 \mathrm{bc}$ & $35.0 \mathrm{a}$ & $60.0 \mathrm{a}$ \\
\hline $\begin{array}{l}\text { Broad bean with phacelia } \\
\text { sown in the centre of plot }\end{array}$ & $1.1 \mathrm{ab}$ & $0.7 \mathrm{a}$ & $0.5 \mathrm{a}$ & $0.8 \mathrm{a}$ & $67.5 \mathrm{c}$ & $45.0 \mathrm{a}$ & $37.5 \mathrm{a}$ & $62.5 \mathrm{a}$ \\
\hline $\begin{array}{l}\text { Broad bean with phacelia } \\
\text { sown at the edges of plot }\end{array}$ & $1.0 \mathrm{ab}$ & $0.9 \mathrm{a}$ & $0.4 \mathrm{a}$ & $0.7 \mathrm{a}$ & $45.0 \mathrm{a}$ & $50.0 \mathrm{ab}$ & $30.0 \mathrm{a}$ & $57.5 \mathrm{a}$ \\
\hline $\begin{array}{l}\text { Phacelia intercropped with } \\
\text { broad bean }\end{array}$ & $1.2 \mathrm{~b}$ & $1.8 \mathrm{~b}$ & $0.4 \mathrm{a}$ & $0.8 \mathrm{a}$ & $65.0 \mathrm{bc}$ & $62.5 \mathrm{c}$ & $32.0 \mathrm{a}$ & $57.5 \mathrm{a}$ \\
\hline
\end{tabular}

*Explanations: see Table 1

plants was observed in the plots where phacelia was sown at the edges of the plots. It can be assumed that phacelia might prevent weevil females from finding the broad bean plants. The differences between the particular combinations were significant and important from the statistical point of view only in the years 2006 and 2007.

Comparing Tables 1 and 2, no dependency between the intensity of beetle feeding on the leaves and the percentage of plants with damaged root nodules was found.

Broad bean beetles were shaken off the plants from the time the first flowers appeared (Tab. 3). In the years 2006 and 2009, the smallest numbers of broad bean beetles were found in plots where phacelia was sown at the edges of the plots and in intercropped plots, whereas in 2007 and 2008, the differences between the particular combinations were insignificant. The statistical differences between the percentages of damaged seeds were found in years 2007 and 2009. In 2007, the smallest percentage of seeds with holes was found on the plots with phacelia intercropped with broad bean, whereas in 2009, it was on plots with phacelia sown in the centre and on the edges of the plots (Tab. 3). The majority of seeds had one beetle exit hole. Only individual seeds had 4-7 beetle exit holes, after the end of the development process. There was no difference between the average number of broad bean beetle exit holes per seed between the combinations (Tab. 4). The feeding of broad bean beetle larvae reduces the seeds' ability to germinate;

Table 3. A comparison of the number of broad been beetles (Bruchus rufimanus Boh.) and the percentage of damaged broad bean seeds

\begin{tabular}{lccccccc}
\hline \multirow{2}{*}{ Crop } & \multicolumn{3}{c}{ Average number of beetles per plant } & \multicolumn{2}{c}{ Percentage of damaged seeds } \\
\cline { 2 - 7 } & 2006 & 2007 & 2008 & 2009 & 2006 & 2007 & 2009 \\
\hline $\begin{array}{l}\text { Broad bean sown as } \\
\text { homogenous crop }\end{array}$ & $0.85 \mathrm{ab}^{*}$ & $1.0 \mathrm{a}$ & $0.6 \mathrm{a}$ & $1.2 \mathrm{~b}$ & $76.3 \mathrm{a}$ & $58.3 \mathrm{~b}$ & $63.9 \mathrm{~b}$ \\
\hline $\begin{array}{l}\text { Broad bean with phacelia } \\
\text { sown in the centre of plot }\end{array}$ & $0.95 \mathrm{~b}$ & $1.1 \mathrm{a}$ & $0.7 \mathrm{a}$ & $0.9 \mathrm{ab}$ & $67.6 \mathrm{a}$ & $53.5 \mathrm{ab}$ & $39.5 \mathrm{a}$ \\
\hline $\begin{array}{l}\text { Broad bean with phacelia } \\
\text { sown at the edges of plot }\end{array}$ & $0.65 \mathrm{a}$ & $0.9 \mathrm{a}$ & $0.5 \mathrm{a}$ & $0.8 \mathrm{ab}$ & $69.6 \mathrm{a}$ & $65.4 \mathrm{~b}$ & $36.0 \mathrm{a}$ \\
\hline $\begin{array}{l}\text { Phacelia intercropped with } \\
\text { broad bean }\end{array}$ & $0.75 \mathrm{ab}$ & $1.1 \mathrm{a}$ & $0.4 \mathrm{a}$ & $0.7 \mathrm{a}$ & $70.1 \mathrm{a}$ & $41.0 \mathrm{a}$ & $57.0 \mathrm{~b}$ \\
\hline
\end{tabular}

*Explanations: see Table 1

Table 4. Average number of exit holes of the broad bean beetle (Bruchus rufimanus Boh.) per seed (healthy and damaged seeds were considered)

\begin{tabular}{lcccc}
\hline \multirow{2}{*}{ Year } & \multicolumn{3}{c}{ Crop } \\
\cline { 2 - 4 } & $\begin{array}{c}\text { Broad bean sown as } \\
\text { homogenous crop }\end{array}$ & $\begin{array}{c}\text { Broad bean with phacelia } \\
\text { sown in the centre of plot }\end{array}$ & $\begin{array}{c}\text { Broad bean with phacelia } \\
\text { sown at the edges of plot }\end{array}$ & $\begin{array}{c}\text { Phacelia intercropped } \\
\text { with broad bean }\end{array}$ \\
\hline 2006 & $1.2 \mathrm{a}^{*}$ & $1.1 \mathrm{a}$ & $1.1 \mathrm{a}$ & $1.2 \mathrm{a}$ \\
\hline 2007 & $1.1 \mathrm{a}$ & $1.1 \mathrm{a}$ & $1.0 \mathrm{a}$ & $0.9 \mathrm{a}$ \\
\hline 2009 & $1.1 \mathrm{a}$ & $0.6 \mathrm{a}$ & $0.6 \mathrm{a}$ & 0.0 \\
\hline
\end{tabular}

*Explanations: see Table 1 
Table 5. Dependence between seed size and damage to the seed caused by the broad bean beetle (Bruchus rufimanus Boh.)

\begin{tabular}{|c|c|c|c|c|c|c|}
\hline \multirow{2}{*}{ Year } & \multirow{2}{*}{ Seed size in $\mathrm{mm}$} & \multirow{2}{*}{$\begin{array}{l}\text { Number of } \\
\text { seeds }\end{array}$} & \multirow{2}{*}{$\begin{array}{l}\text { Percentage of seeds } \\
\text { in the particular size } \\
\text { group }\end{array}$} & \multirow{2}{*}{$\begin{array}{c}\text { Number of } \\
\text { damaged } \\
\text { seeds }\end{array}$} & \multicolumn{2}{|c|}{ Percentage of damaged seeds } \\
\hline & & & & & Within the size group & In total \\
\hline \multirow{4}{*}{2006} & up to 19 & 654 & 20.4 & 406 & 62.1 & 12.7 \\
\hline & $20-23$ & 2221 & 69.4 & 1594 & 71.8 & 49.8 \\
\hline & $<24$ & 325 & 10.2 & 269 & 82.8 & 8.4 \\
\hline & total & 3200 & 100.0 & 2269 & - & 70.9 \\
\hline \multirow{4}{*}{2007} & up to 19 & 945 & 29.5 & 465 & 49.2 & 14.5 \\
\hline & $20-23$ & 1601 & 50.0 & 982 & 61.3 & 30.7 \\
\hline & $<24$ & 654 & 20.5 & 392 & 59.9 & 12.3 \\
\hline & total & 3200 & 100.0 & 1839 & - & 57.5 \\
\hline \multirow{4}{*}{2009} & up to 19 & 1026 & 32.1 & 554 & 54.0 & 17.3 \\
\hline & $20-23$ & 2046 & 63.9 & 957 & 46.8 & 29.9 \\
\hline & $<24$ & 128 & 4.0 & 60 & 46.9 & 1.9 \\
\hline & total & 3200 & 100.0 & 1571 & - & 49.1 \\
\hline
\end{tabular}

this refers to the seeds having at least four exit holes (Wiech and Wojciechowicz-Żytko 2000). The infestation of broad bean seeds by $B$. rufimanus on the experimental plots was high; in particular years it varied from $36 \%$ to $76.3 \%$ (Tab. 3). It could be associated with the fact that for many years broad bean was planted in the same area. A significant reduction of seed infestation was observed in 2009, after the hail of 2008, when the broad bean crops were damaged, which could reduce the population of the pest.

No difference in seed damage, depending on the seed size and the particular combination, was determined. Specific dependencies between the total number of seeds in a particular sized group and the percentage of the damaged seeds were detected; the more seeds in a particular group, the more seeds were damaged, as compared to all of the analysed seeds (Tab. 5). The majority of seeds were classified in groups between $20-23 \mathrm{~mm}$, and they comprised between $50 \%$ and $70 \%$ of all analysed seeds. In this size group the seed infestation percentage was the highest; depending on the year, it varied from $30 \%$ to $50 \%$.

On the basis of these results, larvae preferences in selecting the seed size as a place for larvae development could not be determined. Each year the differences were clearly visible, and in 2006 the highest percentage of damaged seeds was in the group of the largest seeds, whereas in 2007 the highest percentage of damaged seeds was in the group of seeds sized between $20-23 \mathrm{~mm}$, and in 2009 the smallest seeds were damaged most often.
Wnuk and Wiech (1996) obtained different results when analysing intercropping pea with white mustard. In comparison to the homogenous pea crops, the number of Sitona spp. larvae and adults was lower in plots where pea was intercropped with white mustard. On the intercropped plantation, infestation by pea beetle was also lower.

Wnuk (1998) determined that on the plots where pea of three cultivars was grown with phacelia or white mustard, the number of thrips was lower and the number of leaves damaged by Sitona adults was lower as compared to the homogenous pea crops. However, in some years the infestation of the pea pods by pea moth was slightly higher on plots with phacelia.

During the analyses conducted by the researchers, no significant differences were detected between the particular combinations regarding infestation by Sitona spp. and B. rufimanus. The differences in the obtained results in comparison to the pea experiment could be caused by morphological factors and the broad bean development process, as well as by a larger number of broad bean and phacelia planting combinations.

\section{CONCLUSIONS}

1. The influence of phacelia planted with broad bean on the presence of weevils (Sitona) and broad bean beetles (B. rufimanus) as broad bean pests was not found.

2. A smaller amount of broad bean seeds damaged by the broad bean beetle was noted only in some 
of the years in the plots in which the phacelia was intercropped with broad bean.

\section{ACKNOWLEDGEMENTS}

The studies were financed by the Ministry of Science and Higher Education as a part of project No: N 310052 31/2349.

\section{REFERENCES}

Boczek J., 1984. Rozstawa roślin, zachwaszczenie i współrzędna uprawa a porażenie przez szkodliwe owady. Wiad. Entomol. 5: 17-24.

FinCH S., 1996. „Appropriate / inappropriate landings” a mechanism for describing how undersowing with clover affects host plant selection by pest insects of brassica crops. IOBC/WPRS Bull. 19(11): 102-106.

Finch S., KienEgGer M., 1999. Host-plant finding by insects - ,appropriate / inappropriate landings" a mechanism based on the behaviour of pest insects of cruciferous crop. Integrated Control in Field Vegetable Crops IOBC Bull. 22(5): 157-161.

JABŁOŃSKI B., 2000. O potrzebie i możliwościach poprawy pożytków pszczelich. Oddział Pszczelnictwa Instytutu Sadownictwa i Kwiaciarstwa w Puławach: 77.

VAn Emden H.F., DĄBRowski Z.T., 1994. Biodiversity and habitat modification in pest management. Insect Sci. Appli. 15(6): 605-620.

WIECH K., 1993. Wpływ współrzędnej uprawy późnej kapusty z koniczyną białą i fasolą szparagową na występowanie szkodliwej i pożytecznej entomofauny. Rozpr. habilitacyjna. Zesz. Nauk. AR w Krakowie 177: 1-74.

Wiech K., Wojciechowicz-Żytкo E., 2000. Wpływ stopnia uszkodzenia nasion bobu przez strąkowca bobowego (Bruchus rufimanus Boh.) na wzrost i plonowanie roślin. Zesz. Nauk. AR w Krakowie, Sesja Naukowa 71:363-365.

WNUK A., 1998. Effect of intercropping of pea with tansy phacelia and white mustard on occurrence of pest. Folia Hort. 10(1): 67-74.

WNUK A., WIECH K., 1996. The effect of spacing, date of sowing and intercropping on the occurrence of pea pests. Roczn. Nauk Roln., Ser. E 25(1/2): 9-14.

Wnuk A., Wojciechwicz-Żytкo E., 2007. Effect of intercropping of broad bean (Vicia faba L.) with tansy phacelia (Phacelia tanacetifolia Benth.) on the occurrence of Aphis fabae Scop. and predatory Syrphidae. Monograph Aphids and Other Hemipterous Insects 13: 211-217.

\section{WPŁYW UPRAWY BOBU Z FACELIĄ NA WYSTĘPOWANIE OPRZĘDZIKÓW (SITONA SPP.) I STRĄKOWCA BOBOWEGO (BRUCHUS RUFIMANUS BOH.)}

Streszczenie: W latach 2006-2009 prowadzono badania nad wpływem uprawy bobu $\mathrm{z}$ facelią na występowanie oprzędzików i strąkowca bobowego. Przy ocenie szkodliwości oprzędzików uwzględniono żerowanie chrząszczy na liściach (liczba wyżerek na liściu i liczbę uszkodzonych liści) oraz żerowanie larw $\mathrm{w}$ brodawkach korzeniowych bobu. Ocenę szkodliwości larw strąkowca bobowego dokonywano na zebranych nasionach. Nie stwierdzono wpływu facelii na występowanie oprzędzików (Sitona) i strąkowca bobowego (Bruchus rufimanus) jako szkodników bobu. Mniej uszkodzonych nasion przez strąkowca bobowego zanotowano tylko w niektórych latach na poletkach gdzie wysiana była facelia.

Received December 14, 2009; accepted December 17, 2010 